\title{
Kemampuan Motorik Halus Anak Melalui Media Motor Skills Block Interlocking System
}

\section{Ulya Latifah}

RA Qurrota A'yun Rancaekek Bandung

Jl. Bojong Gempol, Desa Haurpugur, Kecamatan Rancaekek, Kabupaten Bandung

Email: ulyalatifah30@gmail.com

$$
\text { Naskah diterima: } 05 \text { Agustus 2019, direvisi: } 16 \text { September 2019, diterbitkan: } 27 \text { September } 2019
$$

\section{Abstrak}

Penelitian ini bertujuan untuk mengetahui perbedaan kemampuan motorik halus anak melalui media Motor Skills Block Interlocking System dengan media balok di kelompok B RA Qurrota A'yun Rancaekek Bandung. Metode yang digunakan dalam penelitian adalah kuasi eksperimen dengan desain penelitian non equivalent control group design. Subjek pada penelitian ini adalah anak kelompok B RA Qurrota A'yun Rancaekek Bandung dengan menggunakan 2 kelas yaitu kelas B1 dan B2 sebanyak 28 anak yang terdiri dari kelas B1 sebagai kelas kontrol 15 anak dan B2 sebagai kelas eksperimen 13 anak. Teknik pengumpulan data yang digunakan adalah unjuk kerja dan dokumentasi, adapun teknik analisis data menggunakan analisis komparasi. Hasil penelitian menunjukkan bahwa kemampuan motorik halus anak menggunakan media Motor Skills Block Interlocking System diperoleh nilai rata-rata pretest sebesar 63 dengan kategori cukup dan posttest sebesar 80 dengan kategori sangat baik. Sedangkan kemampuan motorik halus anak menggunakan media balok diperoleh nilai ratarata pretest sebesar 58 dengan kategori kurang dan posttest sebesar 60 dengan kategori cukup. Terdapat perbedaan yang signifikan antara kemampuan motorik halus anak menggunakan media Motor Skills Block Interlocking System dengan media balok. Hal ini dibuktikan dari hasil uji hipotesis yang menunjukkan nilai $\mathrm{t}_{\text {hitung }}=2,799>\mathrm{t}_{\text {tabel }}=2,056$ pada taraf signifikansi $5 \%$.

Kata kunci: Kemampuan, Media Motor Skills Block Interlocking System, Motorik Halus

\begin{abstract}
This study aims to determine the differences in fine motor skills of children through the Motor Skills Block Interlocking System with block media in B RA Qurrota A'yun Rancaekek. Bandung. The method used in this research is a quasi-experimental research design with a non equivalent control group design. The subjects in this study were children of group B RA Qurrota A'yun Rancaekek. Bandung using 2 classes,
\end{abstract}


namely class B1 and B2 as many as 28 children consisting of class B1 as a control class of 15 children and B2 as an experimental class of 13 children. Data collection techniques used are performance and documentation, while the data analysis technique uses comparative analysis. The results showed that the fine motor skills of children using the Motor Skills Block Interlocking System media obtained an average pretest value of 63 with a sufficient category and posttest of 80 with a very good category. While the fine motor skills of children using media beam obtained an average pretest value of 58 with less categories and posttest of 60 with enough categories. There is a significant difference between children's fine motor skills using Motor Skills Block Interlocking System and block media. This is evidenced from the results of hypothesis testing which shows the value of $t_{\text {count }}=2.799>t_{\text {table }}=2.056$ at a significance level of $5 \%$.

Keywords: Ability, Media, Fine Motor, Motor Skills Block Interlocking System.

\section{Pendahuluan}

Pendidikan anak usia dini diakui sebagai sesuatu yang sangat penting dalam rangka merencanakan generasi kelak yang kuat dan unggul. Setiap informasi yang anak terima akan tersimpan dalam memori otak anak hingga dewasa. Menurut Rasyid (2009: 48) usia dini merupakan usia emas (golden age) dimana anak akan mudah mengikuti, menerima, melihat dan mendengar segala sesuatu yang dicontohkan, diperdengarkan dan diperlihatkan dari lingkungan sekitarnya.

Pendidikan anak usia dini dalam implementasi pembelajarannya menumbuhkan beberapa aspek perkembangan, lingkup perkembangan anak melalui pendidikan prasekolah meliputi: 1) nilai agama dan moral; 2) motorik yaitu motorik kasar dan motorik halus; 3) kognitif; 4) bahasa; dan 5) sosial emosional yaitu menunjukkan respon emosi (Permendiknas 58 Tahun 2009). Aspek perkembangan anak usia dini perlu diberikan stimulasi dengan tepat pada tahap perkembangannya dan diharapkan berkembang secara seimbang antara aspek satu dengan aspek yang lain khususnya aspek perkembangan motorik.

Menurut Samsudin (2008: 10) motorik adalah terjemahan dari kata (motor), karena motorik mengakibatkan terjadinya suatu gerak (movement), maka setiap penggunaan kata motorik selalu dikaitkan dengan gerak. Namun yang harus diperhatikan adalah bahwa gerak yang dimaksudkan di sini bukan hanya semata-mata berhubungan dengan Menurut Soelaiman (2007: 112) kemampuan adalah sifat bawaan sejak lahir dan ditekuni yang memungkinkan seseorang agar dapat menuntaskan pekerjaannya baik secara fisik maupun mental. 
Adapun menurut Sumantri (2005: 143) bahwa kemampuan motorik halus adalah koordinasi penggunaan kelompok otot-otot kecil yang meliputi jari dan tangan yang membutuhkan kecermatan mata dengan tangan, serta kemampuan yang mencakup penggunaan memanfaatkan alat-alat untuk mengerjakan sesuatu gerak seperti yang dilihat sehari-hari yaitu geraknya anggota tubuh (tangan, lengan, kaki dan tungkai) melalui alat gerak tubuh (otot dan rangka). Tetapi gerak di dalamnya melibatkan fungsi motorik seperti otak, saraf, otot, dan rangka.

Wiyani (2014: 55) mengungkapkan bahwa bagi anak usia dini perkembangan fisikmotorik yang optimal sangatlah penting, hal itu karena perkembangan fisik-motorik anak secara langsung ataupun tidak akan memberikan pengaruh terhadap perilakunya sehari-hari. Secara langsung perkembangan fisik-motorik pada anak usia dini akan sangat menentukan kemampuan anak dalam bergerak, sedangkan secara tidak langsung perkembangan fisikmotorik pada anak usia dini akan berpengaruh terhadap cara pandang ataupun perlakuan anak terhadap dirinya dan orang lain. Hal itu akan sangat tampak sekali ketika lingkungan menuntut anak untuk beradaptasi.

Sumantri (2005: 148) menyatakan bahwa pendekatan perkembangan kemampuan motorik halus anak usia dini hendaknya mencermati beberapa prinsip-prinsip sebagai berikut: berorientasi pada kebutuhan anak, belajar sambil bermain, kreativitas dan inovatif, lingkungan kondusif, tema,mengembangkan keterampilan hidup, menggunakan kegiatan terpadu, serta kegiatan berorientasi pada prinsip-prinsip perkembangan anak.

Dalam proses belajar mengajar terdapat dua unsur yang sangat penting, yaitu metode mengajar dan media pembelajaran. Kedua aspek ini saling berkaitan. Pemilihan salah satu metode mengajar akan mempengaruhi jenis media pembelajaran yang sesuai. Pembelajaran khususnya bagi anak usia dini, dibutuhkan media sebagai alat pendukung pembelajaran. Kata media berasal dari bahasa latin medius yang secara harfiah berarti tengah, perantara, atau pengantar. Sebagaimana Asnawir (2002: 19) mengemukakan bahwa: media pengajaran merupakan sarana yang digunakan dalam proses kegiatan pembelajaran sebagai upaya dalam meningkatkan mutu yang ingin dicapai sekolah. Dengan demikian, penggunaan media pembelajaran dianjurkan agar menstimulasi aspek perkembangan anak sehingga pembelajaran berjalan dengan efektif dan mampu mengatasi rasa bosan pada anak.

Beriringan dengan pendapat di atas, Gerlach dan Ely (Arsyad, 2011: 3) menegaskan bahwasannya media secara garis besar adalah manusia, materi, atau kejadian yang membangun kondisi untuk membuat siswa mampu memperoleh pengetahuan, 
keterampilan atau sikap. Dalam pengertian ini guru, buku, dan lingkungan sekolah merupakan media.

Salah satu media pembelajaran yang digunakan oleh lembaga pendidikan anak usia dini adalah balok. Sebagaimana dikemukakan oleh Departemen Pendidikan Nasional (2007: 1) Balok merupakan bongkahan-bongkahan kayu polos (tanpa dicat) sama tebalnya panjang dua kali atau empat kali sama besarnya dengan satu unit balok. Balok juga terdiri dari berbagai bentuk meliputi bentuk segitiga, segiempat, lingkaran balok ini bisa dimainkan sendiri oleh anak maupun berkelompok.

Adapun dengan cara menyenangkan yakni dengan media Motor Skills Block Interlocking System, media ini merupakan merek dagang untuk alat edukasi yang digunakan LAMAC sebagai sarana melatih motorik halus dan kreativitas anak. Adapun pencipta Motor Skills Block Interlocking System yaitu Sonjaya Gazali dan Hendra Widjaja. Motor Skills Block Interlocking System sebagai penyeimbang antara perkembangan teknologi (media touch screen) dengan proses perkembangan anak khususnya melatih motorik halus, konsentrasi dan kreativitas anak serta mendukung anak untuk menjadi lebih cerdas, kreatif, inovatif, imajinatif, dan percaya diri.

Berdasarkan studi pendahuluan di RA Qurrota A'yun Rancaekek Bandung terlihat bahwa kemampuan motorik halus anak masih terdapat yang belum berkembang sesuai dengan standar tingkat pencapaian perkembangan anak. Beberapa anak menunjukkan keterlambatan dalam kemampuan motorik halusnya terutama dalam kegiatan menyusun balok, yang ditandai dengan belum terampilnya anak dalam penggunaan media tersebut di dalam kelas.

Tujuan penelitian ini untuk mengetahui perbedaan kemampuan motorik halus anak melalui media Motor Skills Block Interlocking System dengan media balok di kelompok B RA Qurrota A'yun Rancaekek Bandung.

\section{Metodologi}

Suatu metode penelitian memiliki rancangan penelitian, rancangan ini menggambarkan prosedur yang harus ditempuh, waktu penelitian, sumber data, dan dengan cara bagaimana data tersebut dihimpun dan diolah (Sukmadinata 2012: 52). Menurut Mahmud (2011: 98) bahwa terdapat banyak metode penelitian atau model rancangan penelitian yang biasa digunakan dalam penelitian bidang pendidikan. Untuk melakukan penelitian, peneliti dapat memilih jenis metode sesuai dengan masalah, tujuan penelitian, 
dan kerangka pemikiran yang dirancang. Apakah masalah penelitian bersifat eksploratif (penjajagan), deskriptif (penggambaran), atau eksplanatif (penjelasan) tentu saja akan berpengaruh pada penentuan jenis metode yang akan digunakan.

Metode yang digunakan dalam penelitian ini, yaitu menggunakan metode kuantitatif kuasi eksperimen dengan menggunakan desain penelitian non equivalent control group design (Sugiyono, 2016: 116). Pada desain penelitian non equivalent control group design, penelitian diawali dengan tahap observasi awal pada kemampuan motorik halus anak usia dini (pretest), kemudian diberikan satu kali tindakan (treatment) berupa kegiatan dengan media Motor Skills Block Interlocking System, selanjutnya penelitian diakhiri dengan sebuah observasi akhir (post-test) untuk mengukur perkembangan kemampuan motorik halus pada anak dan kemudian dibandingkan dengan keadaan sebelum diberi perlakuan (treatment). Zainal Arifin (2011: 215) menjelaskan bahwa populasi atau universe adalah objek secara keseluruhan yang digunakan untuk pelitian terkait dengan orang, benda, kejadian, nilai, maupun hal-hal yang terjadi. Adapun yang dijadikan populasi dalam penelitian ini adalas siswa kelas B RA Qurrota A'yun Rancaekek Bandung yaitu pada Kelompok B yang terdiri dari dua kelas yaitu B1 dan B2, dengan jumlah anak sebanyak 28 orang dengan rincian kelas B1 sebanyak 15 orang sebagai kelas eksperimen dan kelas B2 sebanyak 13 orang sebagai kelas kontrol.

Terdapat dua hal utama yang mempengaruhi kualitas data hasil penelitian, yaitu kualitas instrumen penelitian dan kualitas pengumpulan data. Menurut Hasan (2002: 83) pengumpulan data ialah sebagian atau seluruh elemen populasi yang menunjang atau mendukung penelitian terkait pencatatan peristiwa, hal-hal atau keterangan-keterangan atau karakteristik-karakteristik. Pada dasarnya meneliti adalah melakukan pengukuran terhadap fenomena sosial maupun alam, sehingga diperlukan alat ukur yang baik supaya menghasilkan pengukuran yang tepat dan akurat. Teknik pengumpulan data yang digunakan dalam penelitian ini adalah dengan menggunakan teknik unjuk kerja dan dokumentasi. Instrumen penelitian yang digunakan adalah lembar unjuk kerja yang terdiri dari tiga indikator, yaitu: a) meniru bentuk; b) membangun koordinasi tangan, mata, dan pikiran; dan c) melatih respon motorik, dengan jumlah item pernyataan sebanyak 20 butir item. Analisis data pada penelitian ini menggunakan analisis parsial untuk mengetahui skor pada saat pretest dan posttest kedua media, lalu dilakukan uji $\mathrm{t}$ dua kelompok untuk pengolahan hipotesis komparatif serta mengetahui tingkat perbedaan kedua metode. 


\section{Hasil dan Diskusi}

Suatu penelitian diharapkan memperoleh hasil sesuai dengan tujuan yang ditetapkan. Hasil dari penelitian ini berupa data yang kemudian dianalisis dengan teknik dan metode yang telah ditentukan. Adapun data yang dianalisis dalam penelitian ini yaitu data hasil unjuk kerja tentang kemampuan motorik halus anak melalui media Motor Skills Block Interlocking System pada saat pretest maupun posttest di RA Qurrota A'yun Rancaekek Bandung kelompok B1 sebagai kelas eksperimen dan kelompok B2 sebagai kelas kontrol.

Berdasarkan analisis data yang sudah ditentukan, dilakukan analisis parsial untuk menjawab submasalah nomor 1 dan 2 menguji dan menghitung skor rata-rata secara terpisah yang hasil perhitungan nilai rata-rata setiap itemnya diinterpretasikan pada kriteria penilaian menurut Syah (2011: 151) berikut ini:

Tabel 1. Interpretasi Nilai Rata-rata Kemampuan Motorik Halus

\begin{tabular}{cc}
\hline Angka & Skor \\
\hline $80-100$ & Sangat Baik \\
$70-79$ & Baik \\
$60-69$ & Cukup \\
$50-59$ & Kurang \\
$0-49$ & Gagal
\end{tabular}

Sedangkan submasalah nomor 3 dilakukan analisis komparatif, analisis ini digunakan untuk menguji ada tidaknya perbedaan antar variabel yang sedang diteliti, sehingga diperoleh kesimpulan apakah perbedaan itu cukup berarti (signifikan) atau hanya kebetulan. Hal yang perlu diperhatikan berkenaan dengan statistik inferensial untuk menguji dua perlakuan yang diperbandingkan adalah persyaratan normalitas data dan homogenitas varian data (Subana, 2000: 167).

Berdasarkan perhitungan kemampuan motorik halus anak melalui media Motor Skills Block Interlocking System (kelas eksperimen) di RA Qurrota A'yun Rancaekek Bandung saat pretest memiliki nilai tertinggi 73 , nilai terendah 54 , dan nilai rata-rata 63 . Sedangkan pada saat posttest memiliki nilai tertinggi 94 , nilai terendah 60 , dan nilai rata-rata 80 artinya bahwa setelah menggunakan media Motor Skills Block Interlocking System, nilai rata-rata kemampuan motorik halus anak di kelas eksperimen berada pada kategori sangat baik.

Kemampuan motorik halus anak melalui media balok (kelas kontrol) di RA Qurrota A'yun Rancaekek Bandung saat pretest memiliki nilai tertinggi 64, nilai terendah 50 dan nilai rata-rata 58. Sedangkan posttest memiliki nilai tertinggi 70 , nilai terendah 51, dan nilai rata- 
rata 60 artinya bahwa setelah menggunakan tari daerah, nilai rata-rata kemampuan motorik kasar anak di kelas kontrol berada pada kategori kurang. Hasil analisis pretest dan posttest media Motor Skills Block Interlocking System (kelas eksperimen) dan media balok (kelas kontrol) terlebih dahulu dilakukan uji persyaratan, yaitu uji normalitas dan uji homogenitas yang diuraikan sebagai berikut:

Berdasarkan perhitungan uji normalitas hasil data pretest dari Kemampuan Motorik Halus Anak melalui media Motor Skills Block Interlocking System (Kelas Eksperimen) diperoleh nilai mean $(\bar{x})=63$ dan standar deviasi $(\mathrm{SD})=4,83$. Selain itu, diperoleh $\chi_{\text {hitung }}^{2}=$ 2,080 dan $\chi_{\text {tabel }}^{2}=5,991$ dengan derajat kebebasan $(\mathrm{db})=2$ pada taraf signifikansi $5 \%$. Karena $\chi_{\text {hitung }}^{2}=2,080<$ dari $\chi_{\text {tabel }}^{2}=5,991$, maka dapat diinterpretasikan data berdistribusi normal. Sedangkan hasil data pretest dari Kemampuan Motorik Halus Anak melalui media balok (Kelas kontrol) diperoleh nilai mean $(\bar{x})=58$ dan standar deviasi $(\mathrm{SD})=4,39$. Selain itu, diperoleh $\chi_{\text {hitung }}^{2}=2,124$ dan $\chi_{\text {tabel }}^{2}=5,991$ dengan derajat kebebasan $(\mathrm{db})=2$ pada taraf signifikansi $5 \%$. Karena $\chi_{\text {hitung }}^{2}=2,124<$ dari $\chi_{\text {tabel }}^{2}=5,991$, maka dapat diinterpretasikan data berdistribusi normal.

Berdasarkan perhitungan uji normalitas hasil data posttest dari Kemampuan Motorik Halus Anak melalui media Motor Skills Block Interlocking System (Kelas Eksperimen) diperoleh nilai mean $(\bar{x})=80$ dan standar deviasi $(S D)=9,42$. Selain itu, diperoleh $\chi^{2}$ hitung $=$ 5,595 dan $\chi_{\text {tabel }}^{2}=5,991$ dengan derajat kebebasan $(\mathrm{db})=2$ pada taraf signifikansi $5 \%$. Karena $\chi_{\text {hitung }}^{2}=5,595<$ dari $\chi_{\text {tabel }}^{2}=5,991$, maka dapat diinterpretasikan data berdistribusi normal. Sedangkan hasil data posttest dari Kemampuan Motorik Halus Anak melalui Media Balok (Kelas kontrol) diperoleh nilai mean $(\bar{x})=60$ dan standar deviasi $(S D)=5,38$. Selain itu, diperoleh $\chi_{\text {hitung }}^{2}=1,457$ dan $\chi_{\text {tabel }}^{2}=5,991$ dengan derajat kebebasan $(\mathrm{db})=2$ pada taraf signifikansi $5 \%$. Karena $\chi_{\text {hitung }}^{2}=1,457<$ dari $\chi_{\text {tabel }}^{2}=5,991$, maka dapat diinterpretasikan data berdistribusi normal.

Berdasarkan perhitungan uji homogenitas hasil data pretest dari Kemampuan Motorik Halus Anak melalui media Motor Skills Block Interlocking System (Kelas Eksperimen) diperoleh nilai varian $(\mathrm{V})=23,31$ dan kegiatan tari daerah (kelas kontrol) diperoleh nilai $\operatorname{varian}(V)=19,27$. Selain itu diperoleh $F_{\text {hitung }}=1,21$ dan $F_{\text {tabel }}=2,64$ dengan derajat kebebasan $(\mathrm{db})=26$ pada taraf signifikansi 5\%. Karena $\mathrm{F}_{\text {hitung }} 1,21<$ dari $\mathrm{F}_{\text {tabel }}$ 2,64 maka dapat diinterpretasikan bahwa kedua data memiliki varian yang homogen.

Berdasarkan perhitungan uji homogenitas hasil data posttest dari Kemampuan Motorik Halus Anak media Motor Skills Block Interlocking System (Kelas Eksperimen) diperoleh nilai 
$\operatorname{varian}(\mathrm{V})=88,81$ dan media balok (kelas kontrol) diperoleh nilai varian $(\mathrm{V})=39,56$. Selain itu diperoleh $\mathrm{F}_{\text {hitung }}=2,24$ dan $\mathrm{F}_{\text {tabel }}=2,64$ dengan derajat kebebasan $(\mathrm{db})=26$ pada taraf signifikansi 5\%. Karena $\mathrm{F}_{\text {hitung }} 2,24<$ dari $\mathrm{F}_{\text {tabel }}$ 2,64 maka dapat diinterpretasikan bahwa kedua data memiliki varian yang homogen.

Hasil uji normalitas dan uji homogenitas media Motor Skills Block Interlocking System (kelas eksperimen) dan media balok (kelas kontrol) pretest dan posttest, didapatkan bahwa keduanya berdistribusi normal dan bersifat homogen. Maka, dalam perhitungan perbedaan rata-ratanya menggunakan uji t. Berdasarkan perhitungan uji t data hasil pretest diperoleh nilai thitung sebesar 1,300 dan nilai tabel pada taraf signifikansi 5\% sebesar 2,056, atau $t_{\text {hitung }}=$ $1,300<\mathrm{t}_{\text {tabel }}=2$ 2,056. Dengan demikian ho diterima dan ha ditolak dan dapat diinterpretasikan bahwa tidak terdapat berbedaan yang signifikan kemampuan motorik halus anak antara kelompok yang menggunakan media Motor Skills Block Interlocking System dan kelompok yang menggunakan media balok. Sedangkan data hasil posttest diperoleh nilai $t_{\text {hitung }}$ sebesar 2,799 dan nilai $t_{\text {tabel }}$ pada taraf signifikansi 5\% sebesar 2,056, atau $t_{\text {hitung }}=2,799$ $>t_{\text {tabel }}=2,056$. Dengan demikian Ho ditolak dan Ha diterima dan dapat diinterpretasikan bahwa terdapat perbedaan yang signifikan kemampuan motorik halus anak antara kelompok yang menggunakan media Motor Skills Block Interlocking System dan kelompok yang menggunakan media balok.

Hasil uji hipotesis menunjukkan terdapat perbedaan kemampuan motorik halus anak, antara anak yang belajar dengan menggunakan media Motor Skills Block Interlocking System (kelas eksperimen) dengan anak yang belajar dengan menggunakan media balok (kelas kontrol) di Kelompok B kelas B1 dan B2 RA Qurrota A'yun Rancaekek Bandung. Media Motor Skills Block Interlocking System ini memiliki tujuan sebagai inovasi baru dalam pemberian stimulus untuk mengembangkan kemampuan motorik halus anak yaitu belajar sambil bermain. Hal ini diperkuat oleh pernyataan Mayesty (1990: 196-197) yang menyatakan bahwa bagi seorang anak, bermain adalah kegiatan yang anak lakukan sepanjang hari karena bagi anak bermain adalah hidup dan hidup adalah permainan. Anakanak umumnya sangat menikmati permainan dan akan terus melakukannya kapanpun anak memiliki kesempatan.

Adapun media Motor Skills Block Interlocking System itu sendiri merupakan media pembelajaran yang termasuk ke dalam salah satu permainan konstruktif dimana kegiatan bermainnya bersifat menciptakan, mewujudkan, membina, dan memperbaiki. Anak beraktivitas menggunakan media ini, membuat sesuatu menyusun dan merangkainya 
sampai menjadi suatu bentuk atau konstruktif. Sejalan dengan hal itu, Suratno (2005: 83-84) mengungkapkan bahwa yang dimaksud dengan permainan konstruktif ialah aktivitas anak didalam bermain melalui perantara berbagai alat maupun benda untuk dapat menciptakan atau menghasilkan suatu karya tertentu. Menurut Soemiarti (2008: 115) manfaat konstruktif melalui bermain adalah anak-anak memperoleh kesempatan untuk melatih kerja sama antara kedua mata, kedua tangan, serta koordinasi fisik.

Penelitian yang relevan dengan penelitian yang dilakukan, berkenaan dengan kemampuan motorik halus melalui media Motor Skills Block Interlocking System dalam proses pembelajaran diantaranya yaitu: penelitian yang dilakukan oleh Nur Halimah (2016) yang berjudul "Peningkatan Kemampuan Motorik Halus Anak Usia Dini melalui Kegiatan Kolase dengan Berbagai Media pada Anak Kelompok B3 di TK Aba Ngoro-Oro Patuk Gunung Kidul". Hasil penelitian dari tindakan yang dilakukan dalam dua siklus, menunjukkan bahwa melalui kegiatan kolase dengan berbagai media dapat meningkatkan kemampuan motorik halus anak usia dini, kriteria BSH ada 18 anak atau sekitar 85,71\%, kriteria MB 3 anak atau 14,29\%, dan untuk kriteria BB sudah tidak ada lagi.

Adapun dalam penelitian yang dilakukan peneliti mengangkat judul: "Kemampuan Motorik Halus Anak melalui Media Motor Skills Block Interlocking System (Kuasi Eksperimen di Kelompok B RA Qurrota A'yun Rancaekek Bandung)”. Persamaannya yaitu sama-sama mengukur kemampuan motorik halus anak. Sedangkan perbedaan penelitian ini yaitu dilihat dari penggunaan media dan jenis penelitian yang digunakan, penelitian yang dilakukan penulis menggunakan media Motor Skills Block Interlocking System dan merupakan jenis penelitian kuasi eksperimen yang membandingkan media Motor Skills Block Interlocking System dengan media balok.

\section{Penutup}

Berdasarkan hasil penelitian yang telah dilakukan di Kelompok B RA Qurrota A'yun Rancaekek Bandung mengenai kemampuan motorik halus anak melalui media Motor Skills Block Interlocking System, maka dapat disimpulkan sebagai berikut:

Kemampuan motorik halus anak pada kelas eksperimen melalui media Motor Skills Block Interlocking System, diperoleh nilai rata-rata pretest sebesar 63. Nilai tersebut berada pada skala 60-69, dengan interpretasi cukup atau berkualifikasi cukup. Sedangkan hasil posttest diperoleh nilai rata-rata sebesar 80. Nilai tersebut berada pada skala 80-100 dengan interpretasi sangat baik atau berkualifikasi sangat baik. Kemampuan motorik halus anak 
pada kelas kontrol melalui media balok, diperoleh nilai rata-rata pretest sebesar 58. Nilai tersebut berada pada skala 50-59, dengan interpretasi kurang atau berkualifikasi kurang. Sedangkan hasil posttest diperoleh nilai rata-rata sebesar 60. Nilai tersebut berada pada skala 60-69, dengan interpretasi cukup atau berkualifikasi cukup. Kemampuan motorik halus anak yang belajar dengan menggunakan media Motor Skills Block Interlocking System dan anak yang belajar dengan menggunakan media balok, menunjukkan terdapat perbedaan yang signifikan. Hal ini ditunjukkan oleh hasil uji t diperoleh harga $t_{\text {hitung }}$ sebesar 2,799 dan $t_{\text {tabel }}$ sebesar 2,056 pada taraf signifikansi 5\% karena harga $t_{\text {biturg }}=2,799>t_{\text {tabel }}=2,056$, maka Ho ditolak dan Ha diterima.

\section{Daftar Pustaka}

Arsyad, A. (2011). Media Pembelajaran. Jakarta: PT. Raja Grafindo Persada.

Asnawir, Basyiruddin. Usman. (2002). Media Pembelajaran. Jakarta: Ciputat.

Depdiknas. (2007). Pedoman Pembelajaran Bidang Pengembangan Fisik/Motorik di Taman Kanakkanak. Jakarta: Departemen Pendidikan Nasional.

Depdiknas. (2009). Peraturan Menteri Pendidikan Nasional No. 58. Jakarta: Direktorat PAUD.

Harun Rasyid, Mansyur, dan Suratno. (2009). Asessmen Perkembangan Anak Usia Dini. Yogyakarta: Multi Pressindo.

Iqbal Hasan. (2002). Analisis Data Penelitian dengan Statistik. Jakarta: Bumi Aksara.

Mahmud. (2011). Metodologi Penelitian Pendidikan. Bandung: Pustaka Setia.

Mayesty, Mary. (1990). Creative Activities for Young Children 4th Ed: Play, Development, and Creativity. New York: Delmar Publisher Inc.

Samsudin. (2008). Pembelajaran Motorik di Taman Kanak-kanak. Jakarta: Prenada Media Group.

Soelaiman. (2007). Manajemen Kinerja: Langkah Efektif untuk. Membangun, Mengendalikan, dan Evaluasi Kerja. Jakarta: PT. Intermedia Personalia Utama.

Soemiarti. (2008). Pendidikan Anak Prasekolah. Jakarta: Rineka Cipta.

Subana. (2000). Statistika Pendidikan. Bandung: Pustaka Setia.

Sugiyono. (2012). Metode Penelitian Kuantitatif dan R\&D. Bandung: Alfabeta.

Sukmadinata, N.S. (2012). Metode Penelitian Pendidikan. Bandung: PT.Remaja Rosdakarya.

Sumantri. (2005). Model Pengembangan Keterampilan Motorik Anak Usia Dini. Jakarta: Departemen Pendidikan Nasional.

Suratno. (2005). Pengembangan Kreativitas Anak Usia Dini. Jakarta: Departemen Pendidikan Nasional.

Syah, Muhibbin. (2011). Psikologi Pendidikan. Bandung: PT. Remaja Rosdakarya.

Wiyani, N. A. (2014). Psikologi Perkembangan Anak Usia Dini. Yogyakarta: Gava Media. 
Zainal Arifin. (2011). Penelitian Pendidikan. Bandung: Rosdakarya.

\section{Biodata Penulis}

Ulya Latifah lahir di Bandung pada tanggal 30 Agustus 1997 dari orang tua yang bernama Ibu Ipah Nispah dan Bapak Agus Yuyu Turlika, sebagai anak pertama dari dua bersaudara, memiliki satu adik laki-laki yang bernama Hikmal Abror. Telah menyelesaikan pendidikan Strata Satu (S1) Pendidikan Islam Anak Usia Dini di Fakultas Tarbiyah dan Keguruan di Universitas Islam Negeri Sunan Gunung Djati Jurusan Pendidikan Islam Anak Usia Dini pada tanggal 23 Oktober 2019. 